\title{
Migrene og vanlig kostholdsrådgivning
}

Jeg har hatt migrene i omtrent 30 år. Dermed har jeg vært mottaker av både legers og legfolks mer eller mindre begrunnede forslag til hvordan jeg skulle bli kvitt mine migreneanfall. Disse forslagene har rommet alt fra klosser under sengebeina til total harmoni i en paradisisk stillhet (jeg har tre barn og et aktivt yrkesliv og har smilt overbærende til slike forslag...). Jeg er sokneprest i en stor Oslo-menighet - men til tross for at mitt yrke befatter seg med tro og håp, er jeg temmelig skeptisk anlagt.

Jeg har i mange år forsøkt å observere hva som kan virke positivt på min migrene. Jeg har for eksempel prøvd å få til en mest mulig regelmessig nattesøvn, har hatt minimalt inntak av sukker og alkohol, har unngått malinglukt og parfyme osv. Men migrenen har vært hardnakket, og det har vært vanskelig å unngå en frekvens på 3-6 migrenedager i uken. Det er mye.

Migrenemedisiner har hatt god effekt. Likevel var timene (eller minuttene) mens jeg vurderte medisininntak (håpet anfallene skulle gå over av seg selv - noe de ikke gjorde) og et par timer inntil full effekt ble oppnådd, preget av smerte, synsforstyrrelser, kvalme, depresjon, tretthet etc. Totalt en betydelig slitasje gjennom mange år! Likevel har jeg stort sett unngått sykedager etter at de nye medisinene kom i midten av 1990 -årene. For øvrig har jeg levd et sunt liv, med et kosthold i tråd med de råd helsemyndighetene har anbefalt - magert og fettfattig: 4-korn med skummet melk, mager ost, grovt brød, frukt, juice. Til tross for grovt mel og grove, sukkerfrie kornblandinger trengte jeg mat relativt ofte (ca. hver 3.-4. time) og hadde stadig symptomer på hypoglykemi.

På forsommeren 2010 leste jeg tilfeldigvis om Sofie Hexebergs bok Frisk med lavkarbo (1), og tenkte at dette kunne være verdt et forsøk - til tross for at hennes forslag til kosthold virket nokså dramatisk sammenliknet med hva jeg tidligere hadde vært vant med. Hun anbefaler seterrømme og helmelk (skrekk og gru!), masse nøtter, frø, kjøtt og fisk, egg og ost, avocado og masse grønnsaker.

I mine åtte første yrkesaktive år var jeg sykepleier. Hexeberg påpeker at også grovt mel fører til blodsukkerstigning og masse insulin i blodbanen - med derpå følgende lavt blodsukkernivå etter kort tid. Og jeg, gamle sykepleier, ble flau over å ha «glemt» at mel selvsagt blir til raske karbohydrater så snart det utsettes for spytt og magesaft. Jeg hadde nøye unngått sukkerinntak, men overså at mitt etter norsk kostholdsrådgivning «riktige» kosthold førte til hyppige perioder med lavt blodsukker.

Jeg tilegnet meg stoffet i boken. Siden jeg er temmelig analytisk, hadde jeg behov for å forstå for å ville gå inn på en kostholdsomlegging. Deretter gikk jeg i gang. Jeg begynte med et kosthold med svært lite karbohydrater - og unngikk mel, poteter og ris i tillegg til sukker. De første par ukene følte jeg meg litt søvngjengeraktig. På kveldstur i nabolaget spurte jeg min turkamerat: «Går jeg nokså sakte?». Svaret var: «Ja, Mari, du går nokså sakte.»

Etter et par uker «våknet» jeg igjen og fikk tilbake min vanlige energi. Det var tydelig at kroppen hadde skjønt at den fra nå av måtte slite litt for å nyttiggjøre seg fett og proteiner som energikilde, uten mulighet til å ta til seg lett tilgjengelig energi fra karbohydrater.

Men noe oppsiktsvekkende skjedde: Det gikk tre uker uten migreneanfall! Så kom menstruasjonen. Skuffet måtte jeg igjen oppleve å få anfall. Etter et par dager var migrenen over - og en ny lang migrenefri periode tok til - inntil ny menstruasjon.

Nå er det gått ni måneder. Jeg lever fortsatt på det samme kostholdet. Jeg passer på å ha med meg egnet mat på jobb - og noen nøtter og frø i reserve. Jeg har ennå ikke våget å teste ut hvor mye karbohydrater jeg kan tåle og likevel unngå migreneanfall. Jeg ligger fortsatt på svært lavt nivå av karbohydrater, og velger å fortsette med det en stund til.

Kortversjonen av hva omleggingen av kostholdet har ført til, er:

- Jeg har ikke hatt så lite migrene på 30 år. Nå har jeg kun migrene i forbindelse med menstruasjon og ved kraftige lavtrykk og tordenvær; faktorer som vanskelig kan kontrolleres. Det betyr 2-4 migrenedager i måneden - mot 3-6 dager i uken tidligere.

- Jeg har ikke vært så mett i hele mitt liv. Det er helt $\mathrm{OK}$ at det går fem timer (eller mer) mellom hvert måltid.

- Etter seks måneder gikk jeg til fastlegen for å sjekke om blodet mitt tålte dette kostholdet som hodet mitt var så glad for. Både kolesterolverdier og andre kostholdsrelaterte prøver var helt fine.

- Og jeg er veldig, veldig glad! Da det gikk opp for meg at jeg ikke lenger skulle slite med migrenen som en normal del av livet, gråt jeg i flere timer. Rett og slett et dypdykk i selvmedlidenhet ved å se tilbake på alle årene som hadde vært så tunge, og som jeg tappert hadde taklet med jobb og barn, forpliktelser og livsutfoldelse. Jeg er blitt spurt om det ikke koster mye å forsake så mange gode matvarer. Men nei! Gevinsten er så verdifull at det kjennes helt greit.

Jeg har valgt å dele gleden over en så stor forandring med noen kjente. Jeg trodde de skulle bli overrasket. Det ble de ikke. Flere har påpekt at ansiktet mitt har forandret seg siden jeg ikke stadig er preget av hodepine. Et drag ved øynene er borte.

Så ble jeg anbefalt av en legevenn å dele mine erfaringer med Tidsskriftets lesere. Herved er de avlevert!

\section{Mari Wirgenes \\ mari.w@online.no \\ Oslo}

Mari Wirgenes (f. 1958)

er cand.theol. og prest i Oslo.

\section{Litteratur \\ 1. Hexeberg S. Frisk med lavkarbo. Oslo: Cappelen Damm, 2010.}

Mottatt 29.3. 2011, første revisjon innsendt 11.5 . 2011, godkjent 26.5. 2011. Medisinsk redaktør Are Brean. 